\title{
A Rare Complication related with Oral Anticoagulant Use: Diffuse Alveolar Hemorrhage (Over 65 Years; Four Case Reports)
}

\author{
Oral Antikoagülan Kullanımı ile ilgili Nadir Bir Komplikasyon: Diffüz \\ Alveoler Hemoraji (65 Yaş Üstü 4 Olgu Sunumu)
}

Serap Duru, Bahar Kurt, Merve Yumrukuz, Esra Erdemir

\begin{abstract}
Diffuse alveolar hemorrhage (DAH) caused by immune and non-immune etiological factors, characterized by diffuse alveolar consolidation, often presents with the clinical triad of dyspnea, hemoptysis and, anemia, as a result of the disruption of the alveolocapillary membrane of the lung. We present four cases, when the patients are over 65 years of age, followed up at our clinic with diffuse alveolar hemorrhage as a rare complication of the uncontrolled use of anticoagulant (Warfarin) therapy.
\end{abstract}

Key words: Lung, warfarin, Diffuse Alveolar Hemorrhage.

According to World Health Organization data, the world's elderly population, which is constantly increasing, is expected to reach 1.2 billion by 2025 (1). Due to the chronic diseases that occur in this age group the amount of drug used increases; hence, they should be regularly monitored. Diffuse alveolar hemorrhage (DAH), is a disorder developing due to immune and nonimmune etiological factors and characterized by shortness of breath, hemoptysis, anemia, and diffuse alveolar consolidation as a consequence of alveocapillary membrane damage in the lungs. Its most common causes are collagen tissue diseases, infectious

\section{Özet}

Diffüz alveoler hemoraji (DAH), immün ve immün olmayan etyolojik faktörlere bağlı olarak gelişen, akciğerlerde alveolokapiller membranın hasarı sonuCu nefes darlığı, hemoptizi, anemi, diffüz alveolar konsolidasyon ile karakterize bir hastalıktır. Burada, kontrolsüz oral antikoagülan (varfarin) kullanımına bağlı kanamalar arasında nadir görülen bir komplikasyon olan DAH nedeni ile kliniğimizde takip edilen 65 yaş üstü dört olguyu sunmayı amaçladık.

Anahtar Sözcükler: Akciğer, varfarin, Diffüz Alveoler Hemoraji.

or toxic exposure, neoplastic diseases, and pulmonary thromboembolism (2). In the elderly population, oral anticoagulants are the most commonly used drugs in order to prevent thromboembolic complications. Various bleeding complications may occur during treatment with oral anticoagulants but the development of DAH is quite rare $(3,4)$. The current report presents four cases of patients above the age of 65 who presented to emergency service consecutively due to DAH, which is a rare complication in warfarin associated hemorrhages.
'Dışkapı Education and Research Hospital, Göğüs Hastalıkları Kliniği, Ankara, Turkey
${ }^{1}$ Clinic of Chest Diseases, Dışkapı Yıdırım Beyazıt Eğitim Araştırma Hastanesi, Ankara

Submitted (Başvuru tarihi): 22.12.2014 Accepted (Kabul tarihi): 1 1.08.2015

Correspondence (iletişim): Serap Duru, Dışkapı Education and Research Hospital, Göğüs Hastalıkları Kliniği, Ankara, Turkey

e-mail: akcalis@hotmail.com 


\section{CASE}

It was understood that four cases (two females) over the age of 65 presented to the emergency service with complaints of shortness of breath, cough and hemoptysis, having used warfarin at an uncontrolled dose for the previous three years. One used it for a previous coronary bypass and atrial fibrillation while the other three for heart valve replacement. On physical examination, in one case with hypoxemic respiratory failure, blood pressure was found to be 100/70 $\mathrm{mmHg}$, heart rate 110/min, respiratory rate 30 breaths/min and body temperature 37 degree. In the examination of the cardiovascular system, tachyarrhythmia was seen and in the respiratory system examination, inspiratory rales were present specifically in the infrascapular region. In the artery blood gas analysis, the $\mathrm{pH}$ was found to be 7.40, $\mathrm{PaCO}_{2} 32.6 \mathrm{mmHg}, \mathrm{PaO}_{2}$ $55 \mathrm{mmHg}$ and arterial oxygen saturation 88\%. The upper respiratory tract examination, carried out by an ear nose throat consultant, yielded normal results.

In the other three cases, the vital findings were as follows: increase in respiratory rate $(\geqslant 20 / \mathrm{min})$, tachycardia, and body temperature 36 degrees and in physical examination inspiratory rales in the bilateral infrascapular region. In all four cases, a decrease in hemoglobin (<10 gr/dl), prolongation of prothrombin time (>10-14 second) and an increase in INR levels (>3) were observed. Other biochemical investigations were normal, other than an increase in serum creatinine level in one case $(>1.1$ $\mathrm{mg} / \mathrm{d}$ ) who had respiratory failure and compliance problems mean they could not undergo the carbon monoxide diffusion test (DLCO). In two cases, an increase in DLCO was established. Differential diagnosis was made for DAH. That is, cytoplasmic and perinuclear cytoplasmic antibody, antiglomerular basement membrane antibodies, antinuclear antibody, anti-ds DNA antibodies, complement level, rheumatoid factor, TORCH panel, serum D-dimer level, urinalysis and genetic examinations were found to be normal. When the histories of being exposed to a toxic agent via inhalation, drugs used and smoking and drug habits were questioned, it was learned that two male patients had a smoking history of 15-20 pack years, but did not have any clinical symptom of chronic airway disease. In order to rule out lung infections that could lead to the same clinical picture, in sputum ARB and gram positive staining was made with no pathogens detected. In the echocardiographic examination, it was established that left ventricle functions were adequate (EF 60\%) apart from one case that had right atrial enlargement and a minimal deficiency in the tricuspid valve.
In PA lung graphies, bilateral widespread alveolar opacities were detected, which were more pronounced in the paracardiac and central areas (Figure 1). In the thorax $\mathrm{CT}$, patchy ground glass infiltration areas accompanied by scattered alveolar filling defects were seen in the lung (Case 2, Figure 2). Although normal bronchial systems were observed in the fiberoptic bronchoscopy (FOB), hemorrhagic foci were observed on mucosa and hence transbronchial biopsy was not carried out (Figure 3). In the obtained hemorragic lavage fluid, hemosiderin laden macrophages were observed in addition to erythrocytes. In the lavage fluid, ARB was (-) and there was no growth in culture. In cytological examination, no malignant cells were observed. Following supportive treatment including oxygen administration, vitamin $\mathrm{K}$ replacement, and erythrocyte suspension and discontinuation of warfarin, clinical and radiological findings rapidly improved and our cases were discharged uneventfully.

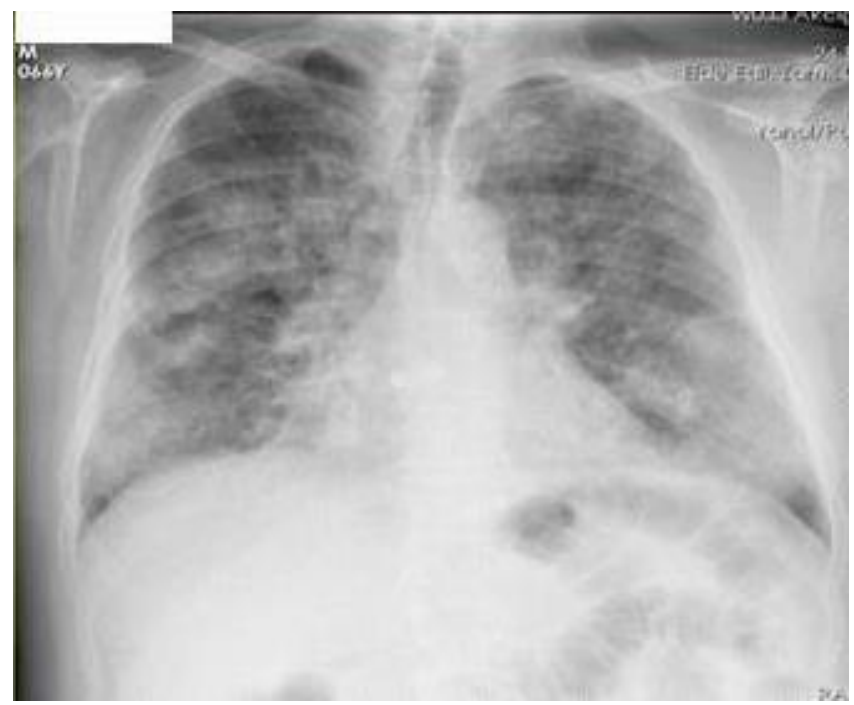

Figure 1: Posteroanterior lung graphy, widespread patched ground glass infiltrations in both lungs

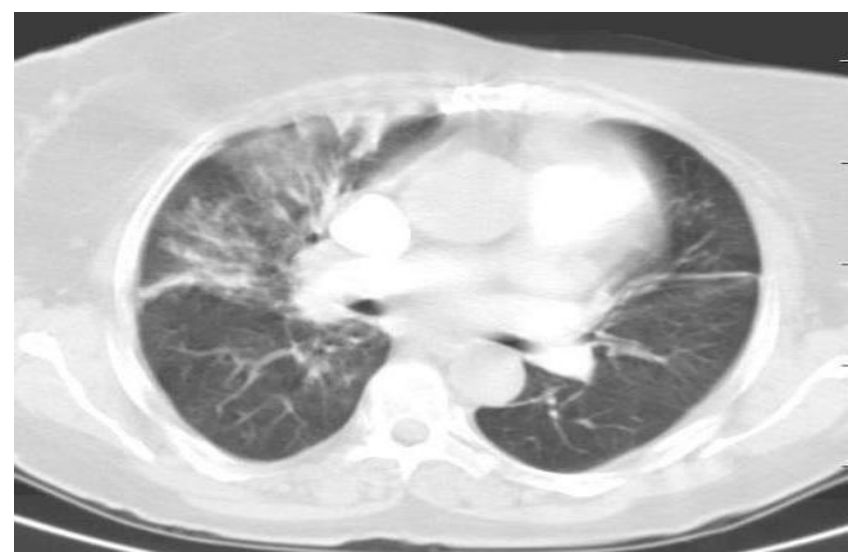

Figure 2: Alveolar filling defects in the thorax computerized tomography section 


\section{DISCUSSION}

Diffuse alveolar hemorrhage, which does not have specific laboratory and clinical diagnosis methods, leads to a clinical picture ranging from cough, hemoptysis, and shortness of breath to respiratory failure, particularly in elderly patients. When this clinical picture is observed in patients on warfarin, infiltrations are detected in the direct lung graphy. Diffuse alveolar hemorrhage should be among the diseases kept in mind in differential diagnosis (5). Of our cases, consistent with this clinical spectrum, cough, hemoptysis and breathlessness was found in three, while in one, additionally respiratory failure was seen. In diffuse alveolar hemorrhages, definitive diagnosis is made by lung tissue biopsy guided using fiberoptic bronchoscopy. Bronchoscopic biopsy may have risk of fatality due to excessive mucosal hemorrhage and severe respiratory failure (6). In this case, the detection of hemosiderin laden alveolar macrophages in bronchoalveolar lavage (BAL) with hemorrhagic appearance, supports the diagnosis. Actually, the appearance of hemosiderin laden alveolar macrophages, in our cases in BAL, suggested the diagnosis of DAH.

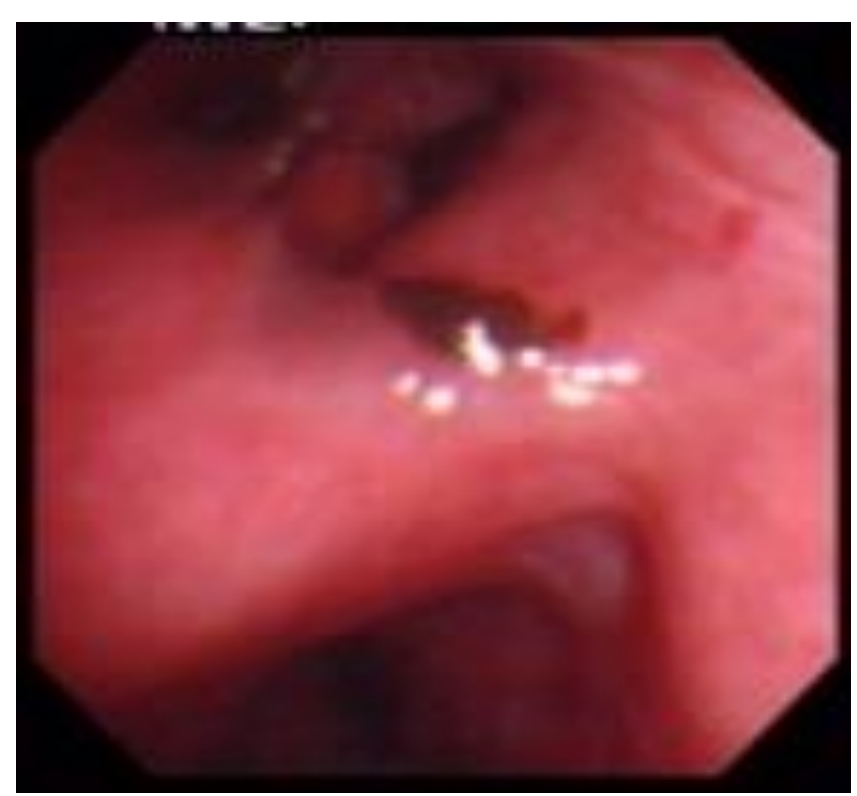

Figure 3: Fiberoptic broncoscopy image; hemorragic foci in the mucosa of entrance to upper lobe of lung

There are many explanations in DAH etiology. Among collagen tissue diseases, Wegener granülomatosis $(7,8)$, systemic lupus erythematosus $(9,10)$ and Goodpasture syndrome (11), give rise to DAH, owing to immune deposits in alveoler interstitium and intra alveolar blood vessels. In addition, drugs such as cocaine, difenylhidantoin and leflunomid may lead to DAH (12). It is determined that, the clinical picture in our cases, is that of
DAH, which occurs rarely without any systematic involvement other than pulmonary involvement. Warfarin is a commonly prescribed anticoagulant all over the world. Diffuse alveolar hemorrhage associated with warfarin, was first described by Brown, et al (13). Subsequently, only a limited number of cases have been presented. $(4,14)$. Therefore, we believe that our series of four cases may contribute the literature regarding this subject. In a previous study, it was reported that of all cases followed up in hospital with side effects of drugs, 10\% were associated with warfarin $(15,16)$. Care should be exercised in the follow up of patients on warfarin and it should be kept in mind that, it may lead to DAH which has a high mortality risk unless diagnosed and treated early.

\section{CONCLUSION}

As a result, DAH is a life threatening complication, which may develop due to many etiologic factors, and it is a catastrophic complication of the uncontrolled use of warfarin, a requiring early diagnosis and investigations before respiratory failure develops. In warfarin associated DAH, especially elderly patients that regularly use the drug, they should be warned against the risk of hemorrhage and should be monitored by clinicians.

\section{CONFLICTS OF INTEREST}

None declared.

\section{AUTHOR CONTRIBUTIONS}

Concept - S.D., E.E., B.K., M.Y.; Planning and Design S.D., B.K., E.E., M.Y.; Supervision - S.D., E.E., M.Y., B.K.; Funding - S.D., M.Y., E.E.; Materials - S.D., B.K.; Data Collection and/or Processing - S.D., B.K., M.Y.; Analysis and/or Interpretation - S.D., E.E., M.Y.; Literature Review - S.D., E.E.; Writing - S.D., B.K., M.Y.; Critical Review S.D., B.K.

\section{YAZAR KATKILARI}

Fikir - S.D., E.E., B.K., M.Y.; Tasarım ve Dizayn - S.D., B.K., E.E., M.Y.; Denetleme - S.D., E.E., M.Y., B.K.; Kaynaklar - S.D., M.Y., E.E.; Malzemeler - S.D., B.K.; Veri Toplama ve/veya İşleme - S.D., B.K., M.Y.; Analiz ve/veya Yorum - S.D., E.E., M.Y.; Literatür Taraması S.D., E.E.; Yazıyı Yazan - S.D., B.K., M.Y.; Eleştirel İnceleme - S.D., B.K.

\section{REFERENCES}

1. World Health Organization (WHO). Elder maltreatment. [Internet] Available from: 
www.who.int/entity/mediacentre/factsheets/fs357/en/. Accessed:2.08.2011.

2. loachimescu OC, Stoller JK. Diffuse alveolar hemorrhage: diagnosing it and finding the cause. Cleve Clin J Med 2008; 75:258-60. [CrossRef]

3. Lee JH, Kim SW. Successful management of warfarinexacerbated diffuse alveolar hemorrhage using an extracorporeal membrane oxygenation. Multidiscip Respir Med 2013; 8:16. [CrossRef]

4. Erdogan D, Kocaman O, Oflaz H, Goren T. Alveolar hemorrhage associated with warfarin therapy: a case report and literature review. Int J Cardiovasc Imaging 2004; 20:155-9. [CrossRef]

5. Schwarz MI, Cherniack RM, Talmadge E, King JR. Diffuse Alveolar hemorrhage and other rare infiltrative disorders. In: Murray JF, Nadel JA (eds). Textbook of Respiratory Medicine. 3rd ed. Philadelphia: W.B. Saunders Company; 2000:733-51.

6. Thomas JK, Jayaprakash K, Misiriya KJ, Khadar SA, Pappachan JM. Catastrophic pulmonary alveolar hemorrhage complicating warfarin therapy. J Assoc Physicians India 2008; 56:34.

7. Marci A, Stoica R, Ion I, Dănilă E, Tănăseanu S. Wegener granulomatosis with severe alveolar hemorrhagic syndrome. Pneumologia 2007; 56:137-41.

8. Cordier JF, Cottin V. Alveolar hemorrhage in vasculitis: primary and secondary. Semin Respir Crit Care Med 2011 ; 32:310-21. [CrossRef]
9. Santos BH, Santos RR, Santos CF, Kakehasi AM, Von Tiesenhausen HA. Pulmonary hemorrhage as a manifestation of systemic lupus erythematosus. Rev Hosp Clin Fac Med Sao Paulo 2004; 59:47-50. [CrossRef]

10. Lara AR, Schwarz MI. Diffuse alveolar hemorrhage. Chest 2010; 137:1164-71. [CrossRef]

11. Kronauer CM, Keusch G, Burger HR, Speich R, Russi EW. Alveolar hemorrhage. Schweiz Med Wochenschr 1989; 119:1454-65.

12. Waness A, Aldabbagh T, Harakati M. Diffuse alveolar haemorrhage secondary to warfarin therapy for atrial fibrillation: a case report and literature review. BMJ Case Rep 2009; 2009: bcr08.2008.0757. [CrossRef]

13. Brown OL, Garvey JM, Stern CA. Roentgenogram of the month. Dis Chest 1965; 48:525-6. [CrossRef]

14. Finley TN, Aronow A, Cosentino AM, Golde DW. Occult pulmonary hemorrhage in anticoagulated patients. Am Rev Respir Dis 1975; 112:23-9.

15. Pirmohamed M, James S, Meakin S, Green C, Scott AK, Walley TJ, et al. Adverse drug reactions as cause of admission to hospital: prospective analysis of 18820 patients. BMJ 2004; 329: 15-9.

16. Burmester JK, Berg RL, Glurich I, Yale SH, Schmelzer JR, Caldwell MD. Absence of novel CYP4F2 and VKORC1 coding region DNA variants in patients requiring high warfarin doses. Clin Med Res 2011; 9:119-24. [CrossRef] 